ISSN 1392-3196 / e-ISSN 2335-8947

Zemdirbyste-Agriculture, vol. 104, No. 1 (2017), p. 63-70

DOI 10.13080/z-a.2017.104.009

\title{
Applicability of Pediococcus strains for fermentation of cereal bran and its influence on the milk yield of dairy cattle
}

\author{
Vita KRUNGLEVICIUTE, Rasa ZELVYTE, Ingrida MONKEVICIENE, Jone KANTAUTAITE, \\ Rolandas STANKEVICIUS, Modestas RUZAUSKAS, Elena BARTKIENE \\ Lithuanian University of Health Sciences \\ Tilžès 18, Kaunas, Lithuania \\ E-mail: vitakrungleviciute@gmail.com
}

\begin{abstract}
The isolated Pediococcus acidilactici BaltBio01 and Pediococcus pentosaceus BaltBio02 strains were cultivated in barley and wheat bran $(90 / 10, \mathrm{~m} / \mathrm{m})$ substrate, and the developed fermented feed stock, with high content of valuable Pediococcus, was used for Lithuanian black and white dairy cattle feeding. In addition, the influence of fermented feed stock on milk production and composition was determined.

Isolated strains demonstrated versatile carbohydrate metabolism, grown at $30^{\circ} \mathrm{C}$ and $37^{\circ} \mathrm{C}$ temperatures, acidic tolerance, showed to be non resistant to antibiotics and have antimicrobial activity. Bioconversion of cereal byproducts (barley and wheat bran) using isolated microorganisms allows production of safer (reduced Enterobacteria, aerobic bacteria, yeast and mould count) fermented feed stock with high content of Pediococcus. At the beginning of the feeding experiment, no significant differences in feed intake, milk production and milk composition were established between the test groups. Control and trial groups received the same ration; however, the trial groups, in addition, received $200 \mathrm{~g}$ per dairy cattle of the fermented feed stock containing $9.6 \log _{10} \mathrm{CFU} \mathrm{g}^{-1}$ Pediococcus daily for 66 days (group B received $200 \mathrm{~g}$ fermented with $P$. acidilactici/dairy cattle/day feed stock, group C received $200 \mathrm{~g}$ fermented with $P$. pentosaceus/dairy cattle/day feed stock, and group D received $200 \mathrm{~g}$ fermented with $P$. acidilactici and $P$. pentosaceus/dairy cattle/day feed stock). After 33 days of experiment, significant milk yield increase in group D (yield $34.64 \pm 3.56 \mathrm{~kg} \mathrm{~d}^{-1}$ ), compared with group A (yield $29.93 \pm 3.55 \mathrm{~kg} \mathrm{~d}^{-1}$ ) and group $\mathrm{C}$ (yield $30.24 \pm 3.99 \mathrm{~kg} \mathrm{~d}^{-1}$ ) was established. After 66 days of feeding, similar trends were found, i.e. milk yield significantly increased in group D (yield $35.04 \pm 3.04 \mathrm{~kg} \mathrm{~d}^{-1}$ ) compared with group A (yield $29.04 \pm 3.88 \mathrm{~kg} \mathrm{~d}^{-1}$ ). It can be inferred that barley and wheat bran could be used to promote growth of $P$. acidilactici BaltBio01 and P. pentosaceus BaltBio02, and the produced fermented feed stock could be recommended for dairy cattle feeding in order to increase milk production.
\end{abstract}

Key words: barley and wheat bran, dairy cattle, fermented feed stock, milk, Pediococcus.

\section{Introduction}

The environmental impact of agricultural by-products from the processing of food crops is an increasing concern worldwide. Currently, cereal bran has been used as a low-value ingredient for both human consumption and animal feed. The most popular bioprocessing technologies for cereal bran nutritional and technological functionality increasing are enzymatic processing and fermentation (Coda et al., 2015), and the most popular starters in fermented feed production are lactic acid bacteria (LAB) including Pediococci, which constitute the most suitable choice for application as protective cultures, since they are present in all fermented substrates with long history of safe use, and form part of the gut microflora of humans and animals (Allen et al., 2013). The scientific community has proposed alternatives to the use of antibiotics, including the use of microorganisms showing positive effect on animal health and productivity parameters (Redondo et al., 2014). In adult ruminants, probiotics have mostly been selected to target the rumen compartment, which is the main site of feed digestion (Chaucheyras-Durand, Durand, 2010). The use of probiotics proved to be effective in increasing milk production of lactating dairy cattle (Vibhute et al., 2011; Salvedia et al., 2015; Shreedhar et al., 2016). Gradual improvement was observed in overall milk composition with supplementation of probiotics (Vibhute et al., 2011).

However, the ruminant digestive system is unique, there are billions of microorganisms which help the dairy cattle to digest and utilize nutrients in the feed. To achieve efficient feed utilization and high milk yield, the microorganisms must have optimal conditions, and the disbalance of this system is highly undesirable. Bacterial antagonism is a common phenomenon in nature; therefore, microbial interactions play a major role in the equilibrium between competing beneficial and potentially pathogenic microorganisms (Balcazar et al., 2006). Most microorganism based products utilize one or more of several types of bacteria. Antimicrobial activities of LAB are due to organic acids, hydrogen peroxide and 
bacteriocins production (Dimitonova et al., 2008). The benefit of many bacteriocins is their low oral toxicity for the treated host. Indeed, many bacteriocins produced by $\mathrm{LAB}$, in particular, have been consumed in fermented feeds as a feed preservative. The same principles apply to bacteriocin producing cultures and their application to control pathogens in the gut (Connor et al., 2015).

According to the FAO/WHO (2006), the development of commercial microbial feed supplements requires their unequivocal taxonomic identification, as well as their in vitro and in vivo functional characterization and safety assessment. In Europe, the European Food Safety Authority (EFSA) proposed a system for a pre-market safety assessment of selected groups of microorganisms used in feed and the production of feed additives leading to a Qualified Presumption of Safety (QPS) status (EFSA, 2011). According to the EFSA approach, most LAB species are included in the QPS list and, therefore, demonstration of their safety only requires confirmation of the absence of determinants of resistance to antibiotics of human and veterinary clinical significance (Muñoz-Atienza et al., 2013). Evidence of the harmlessness of the probiotic to the environment is one important subject for its registration. In general, any negative impact is highly unlikely since all these microorganisms are derived from nature (Yirga, 2015).

The aim of this study was to use spontaneously fermented rye, as a source of the lactic acid bacteria, for the isolation of new strains, and by using isolated strains to develop sustainable technology for fermented feed stock production. In addition, to investigate the influence of developed fermented feed stock on the milk production of Lithuanian black and white dairy cattle.

\section{Materials and methods}

The isolation, identification, and characterisation of the microorganisms were conducted in 2015 at the University of Natural Resources and Life Sciences (BOKU) in Vienna, Austria. Other analyses and experiments with animals were conducted in 2016 at the Lithuanian University of Health Sciences.

Production of spontaneously fermented rye. Spontaneously fermented rye was produced by using the following scheme: $100 \mathrm{~g}$ rye flour $+1 \%$ acetic acid $+1 \%$ salt $+150 \mathrm{ml}$ water $\rightarrow$ fermentation $48 \mathrm{~h}$ at $30^{\circ} \mathrm{C} \rightarrow+50 \mathrm{~g}$ rye flour $+50 \mathrm{ml}$ water $\rightarrow$ fermentation $24 \mathrm{~h}$ at $30^{\circ} \mathrm{C}$.

Purification, isolation and identification of Pediococcus by polymerase chain reaction (PCR)based analysis techniques. Purification of cells was performed according to Kiss et al. (2007). The molecular fingerprinting of the final strains was done by rep-typing with the primer GTG5 (5'-GTG GTG GTG GTG GTG3') (Versalovic et al., 1994). Polymerase chain reaction (PCR) was carried out in a Master Cycler (Eppendorf, Germany). The resulting (GTG)5-PCR fingerprints were analyzed using the software package BioNumerics v4.0 (Applied Maths, Belgium). 16S rDNA sequencing was conducted for selected strains by applying the primers - Bak4 (5'-AGG AGG TGA TCC ARC CGC A-3'), Bak11 (5'-AGT ATTG ATC MTG GCT CAG -3 '), set and PCR protocol published by Di Cello et al. (1997). The PCR products were purified applying the peqGold-Cycle-Pure Kit (Peqlab Biotechnology GmbH, Germany) and sequenced (Eurofins MWG Operon, Austria). The received sequences were analysed with the BLASTn tool (https://blast.ncbi.nlm.nih.gov/Blast. cgi), and a minimum sequence identity of $98 \%$ was chosen as a criterion for species identification. Colonies were identified as belonging to the genus Pediococcus (Pfannebecker, Fröhlich, 2008) by means of PCR. The PCR-based identification on species level followed the strategy by Mora et al. (1997).

Evaluation of isolated Pediococcus carbohydrate metabolism, gas production, tolerance to temperature and low $\mathrm{pH}$ conditions. Carbohydrate fermentation profiles of the strains were determined by using API $50 \mathrm{CH}$ system (BioMerieux, France). Moreover, each pure culture was further characterized by Durham tube method in de Man, Rogosa and Sharpe (MRS) broth at $30^{\circ} \mathrm{C}$ for $24 \mathrm{~h}$ for detecting gas production. The growth performances at 30,37 and $45^{\circ} \mathrm{C}$ for $24 \mathrm{~h}$ in MRS broth were monitored using a Thermo Bioscreen $\mathrm{C}$ automatic turbidometer (Labsystems Oy, Finland). The ability of the strains to survive at low $\mathrm{pH}$ was evaluated in triplicate as described by Lee et al. (2011), in acidified MRS broth (final $\mathrm{pH} 2.5$ ).

The evaluation of Pediococcus resistance to antibiotics. The minimum inhibitory concentrations (MICs) of ten antibiotics: gentamicin (GEN), kanamycin (KAN), streptomycin (STREP), tetracycline (TET), erythromycin (ERY), clindamycin (CLIN), chloramphenicol (CHL), ampicillin (AMP), amoxicillin (AML) and trimethoprim (TM), were determined by E-test method. Interpretation of the results was performed according to the guidance on the assessment of bacterial antimicrobial susceptibility described by EFSA (EFSAFEEDAP, 2012).

The evaluation of antimicrobial activities of isolated Pediococcus. The Pediococcus (P. acidilactici BaltBio01 and $P$. pentosaceus BaltBio02) were grown in MRS medium (Biolife, Italy) at their optimal temperatures ( $P$. acidilactici at $32^{\circ} \mathrm{C}, P$. pentosaceus at $35^{\circ} \mathrm{C}$ ). Two percent of Pediococcus cells were inoculated into a fresh medium and propagated for $18 \mathrm{~h}$. The cells were harvested by centrifugation $\left(6000 \mathrm{~g}, 10 \mathrm{~min}\right.$ and $\left.4^{\circ} \mathrm{C}\right)$. The culture supernatants were filtered through a $0.2 \mathrm{~mm}$ sterile Millipore filter to remove all cells. Supernatants were used for the determination of antimicrobial activities of $P$. acidilactici and P. pentosaceus strains and its mix against variety of pathogenic and opportunistic bacterial strains (Pseudomonas aeruginosa, Staphylococcus aureus, Escherichia coli, Salmonella enterica, Corynebacter spp., Klebsiella pneomoniae, Enterococcus faecalis and Bacillus cereus) previously isolated from diseased cattle. Agar well diffusion assay was used for antimicrobial activities testing. For this purpose, 0.5 McFarland unit density suspension of each pathogenic bacterial strain was inoculated onto surface of cooled Mueller Hinton agar (Oxoid Ltd, UK) using sterile cotton swabs. Wells of $6 \mathrm{~mm}$ in diameter were punched in agar and filled with $50 \mu \mathrm{l}$ of LAB supernatants. The experiments were repeated three times and the average of inhibition zones was calculated. The antimicrobial activities against tested bacteria were determined by measuring the diameter $(\mathrm{mm})$ of inhibition zones.

Preparation of barley and wheat bran fermented feed stock with high content of viable P. acidilactici BaltBio01 and P. pentosaceus BaltBio02. Mix of barley and wheat bran (moisture content 11.6\%; 90/10, m/m) (Biglio dribsniu gamyba Ltd, Lithuania) was used as the fermentation medium for $P$. acidilactici and P. pentosaceus. Before the experiment, Pediococcus strains were stored at $-80^{\circ} \mathrm{C}$ in a Microbank system (Pro-Lab Diagnostics, UK) and were propagated in MRS agar CM0359 (Oxoid Ltd, UK) at $30^{\circ} \mathrm{C}$ for $48 \mathrm{~h}$ with the 
addition of $40 \mathrm{mM}$ fructose and $20 \mathrm{mM}$ maltose prior to use. The bacteria were diluted with a physiological saline to a concentration of $10^{8} \mathrm{CFU} \mathrm{mL} \mathrm{m}^{-1}$ before the cereal bran fermentation.

The fermented product ( $45 \%$ moisture content) was prepared using $100 \mathrm{~kg}$ of cereal bran (barley and wheat bran, $90 / 10, \mathrm{~m} / \mathrm{m}$ ) and $37 \mathrm{~L}$ of water. $\mathrm{LAB}$ cell suspension $(3 \%, \mathrm{~m} / \mathrm{m})$ containing about $10^{8} \mathrm{CFU}$ $\mathrm{mL}^{-1}$ was added, followed by fermentation for $72 \mathrm{~h}$ at temperature optimal for the strains ( $P$. acidilactici at $32^{\circ} \mathrm{C}$, P. pentosaceus at $\left.35^{\circ} \mathrm{C}\right)$. Bran substrate with high content of Pediococcus $\left(10^{9} \mathrm{CFU} \mathrm{g}^{-1}\right)$ was divided into the $200 \mathrm{~g}$ portions and used for dairy cattle feeding. A new portion of fermented feed stock was prepared every 7 days, because Pediococcus count in high moisture bran substrate during the 7 days' period (storage temperature $\left.+4^{\circ} \mathrm{C}\right)$ was stable $\left(10^{9} \mathrm{CFU} \mathrm{g}^{-1}\right)$. Fermented feed stock containing $P$. acidilactici and $P$. pentosaceus strains was produced by mixing fermented with $P$. acidilactici feed stock and fermented with $P$. pentosaceus feed stock in equal parts $(50 / 50, \mathrm{~m} / \mathrm{m})$

Microbiological analysis of the fermented cereal bran. For microbiological analysis $10 \mathrm{~g}$ of sample were homogenized with $90 \mathrm{~mL}$ of saline $(0.9 \%)$. The suspension was diluted, and the $10^{-4}-10^{-8}$ solutions were inoculated in MRS agar CM0361 (Oxoid Ltd, UK) and incubated under anaerobic conditions at $35^{\circ} \mathrm{C}$ for $72 \mathrm{~h}$ (for Pediococcus strains). MacConkey agar CM0007B (Oxoid Ltd, UK) was used for determination of total count of Enterobacteria, the Nutrient agar (Biolife Italiana Srl, Italy) was used for total aerobic bacteria, and the Sabouraud glucose agar C974Q82 (Sigma-Aldrich, Germany) was used for fungi, followed the incubation under aerobic conditions at $37^{\circ} \mathrm{C}$ for $72 \mathrm{~h}$. A final number of bacteria was calculated and expressed as a $\log _{10}$ of colony forming units (CFU) per gram of sample. Three replications per treatment were prepared.

Experimental animals and diets, milk samples collection and analyses. Effects of P. acidilactici and $P$. pentosaceus fermented feed stock and its mix were investigated on 160 mid-lactation dairy cattle divided into four groups each containing 40 animals: control (A) and trial (B, C and D) animals were cared for according to the Requirements for keeping, maintenance and use of animals intended for experimental and other scientific purposes (Valstybès žinios, 2012). The experiment was performed in the winter at a farm of Lithuanian black and white dairy cattle. Division of the dairy cattle into groups was based on parity, body weight and stage of the lactation cycle. All dairy cattle passed general health examinations monthly throughout. Control and trial groups received identical diet (Table 1). Nutrient composition in $1 \mathrm{~kg}$ of diet in dry matter: net energy lactation $7.33 \mathrm{MJ}$, crude protein $17.0 \%$, crude fat $5.70 \%$, crude fibre $15.0 \%$.

Table 1. Ingredients of the diets fed to dairy cattle

\begin{tabular}{lclc}
\hline Diet composition & $\begin{array}{c}\text { Weight } \\
\mathrm{kg}\end{array}$ & Diet composition & $\begin{array}{c}\text { Weight } \\
\mathrm{kg}\end{array}$ \\
\hline Haylage & 14.0 & Mineral supplement & 0.35 \\
Corn silage & 12.0 & Sugar beet pulp & 2.5 \\
Haulm & 0.5 & Corn grain silage & 3.5 \\
Molasses & 1.0 & Salt & 0.05 \\
Triticale & 2.5 & Corn grain & 2.0 \\
Soybean meal & 1.5 & Soda & 0.15 \\
Rapeseed expeller & 2.0 & Protected fat & 0.3 \\
\hline
\end{tabular}

However, the trial groups additionally received $200 \mathrm{~g}$ per dairy cattle of the fermented feed stock daily during 66 days (group B received $200 \mathrm{~g}$ fermented feed stock containing $9.6 \log _{10} \mathrm{CFU} \mathrm{g}^{-1}$ of $P$. acidilactici/dairy cattle/day, group $\mathrm{C}$ received $200 \mathrm{~g}$ fermented feed stock containing $9.6 \log _{10} \mathrm{CFU} \mathrm{g^{-1 }}$ of $P$. pentosaceus/dairy cattle/day, group D received $200 \mathrm{~g}$ fermented feed stock containing $9.6 \log _{10} \mathrm{CFU} \mathrm{g}{ }^{-1}$ of $P$. acidilactici/dairy cattle/ day and $P$. pentosaceus/dairy cattle/day). The fermented feed stock supplements were fed individually. Control group received $200 \mathrm{~g}$ nonfermented barley and wheat bran $(90 / 10, \mathrm{~m} / \mathrm{m})$. The daily feed intake on a dry matter (DM) basis was determined by the measurement of differences between the feed offered and orts. Orts were collected every day. Water was available ad libitum.

Milk samples from all experimental dairy cattle $(\mathrm{n}=160)$ were collected and daily milk yields were recorded during control milking three times: first - at the beginning of the experiment, i.e. one day before starting the feeding of the fermented feed stock supplement, second - after 33 days of the feeding of the fermented feed stock supplement, and third - after 66 days of the feeding of the fermented feed stock supplement. Milk yield adjusted to $4 \%$ fat-corrected milk (FCM) was calculated with the following equation: $4 \% \mathrm{FCM}=0.4 \times$ actual milk yield (in $\left.\mathrm{kg} \mathrm{d}^{-1}\right)+15 \times$ milk fat (in $\mathrm{kg} \mathrm{d}^{-1}$ ). The following parameters of milk were measured: milk fat, milk protein, milk lactose, milk urea by the equipment LactoScope FTIR, FT1.0. 2001 (Delta Instruments, Holland).

Statistical analysis. The experimental data were evaluated statistically and presented as mean \pm standard error of the mean (mean \pm SEM). The significance of arithmetic differences $(p)$ was defined according to the Student's $t$-test. In order to evaluate the influence of different factors (type of Pediococcus strain and duration of feeding with fermented feed stock supplements) and their interaction on dairy cattle milk production, the data were subjected to two-way analysis of variance (ANOVA), statistical program $R 3.2 .1$ ( $R$ Core Team, 2015). The results were referred to statistically significant at $p<0.05$.

\section{Results and discussion}

The properties of isolated Pediococcus strains. Identification of the isolated Pediococcus strains by using the software package BioNumerics v4.0, as well as carbohydrate metabolism, gas production, tolerance to temperature and low $\mathrm{pH}$ conditions $(\mathrm{pH} 2.5$ for $2 \mathrm{~h}$ of incubation) are shown in Table 2.

Many factors contribute to a successful fermentation of carbohydrate-rich feeds, and metabolic activities of used microorganisms play a leading role. All the tested strains were able to ferment L-arabinose, D-ribose, D-xylose, D-galactose, D-glucose, D-fructose, D-mannose, N-acetylglucosamine, amygdalin, arbutin, esculin, salicin, D-cellobiose, D-trehalose, gentiobiose and D-tagatose. Some differences between carbohydrate metabolism in the analyzed Pediococcus strains were observed, only $P$. acidilactici was able to ferment L-rhamnose, methyl- $\alpha \mathrm{D}$-mannopyranoside and potassium gluconate, and only $P$. pentosaceus showed high activity (+++) of D-maltose, D-melibiose, D-saccharose, D-raffinose and low activity $(+)$ of potassium 2-ketogluconate metabolism. The use of Pediococcus strains showing versatile carbohydrate metabolism, can be of great advantage to the animal, since no digestive enzymes exist for breaking down cellulose or other complex carbohydrates.

All the tested strains were grown at $30^{\circ} \mathrm{C}$ and $37^{\circ} \mathrm{C}$, as well as $P$. acidilactici were grown at $45^{\circ} \mathrm{C}$, and after $2 \mathrm{~h}$ of incubation at $2.5 \mathrm{pH}$, the viable count of 
Table 2. Bands of isolated Pediococcus strains (P. acidilactici BaltBio01 and P. pentosaceus BaltBio02) genus, their carbohydrate metabolism, gas production, tolerance to temperature and low $\mathrm{pH}$

\begin{tabular}{|c|c|c|c|c|c|c|}
\hline \multirow{2}{*}{\multicolumn{2}{|c|}{ Parameters }} & \multirow{2}{*}{$P a$} & \multirow{2}{*}{$P p$} & \multicolumn{3}{|c|}{ Bands of isolated Pediococcus genus } \\
\hline & & & & control marker & $P a$ & $P p$ \\
\hline \multicolumn{2}{|l|}{ L-arabinose } & +++ & +++ & & & \\
\hline \multicolumn{2}{|l|}{ D-ribose } & +++ & +++ & 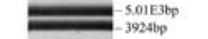 & & $-7.12 \mathrm{Es} \mathrm{bp}$ \\
\hline \multicolumn{2}{|l|}{ D-xylose } & +++ & +++ & $-2095 \mathrm{pp}$ & & -391760 \\
\hline \multicolumn{2}{|l|}{ D-galactose } & +++ & +++ & $-2494 \mathrm{pp}$ & -5.88336 & 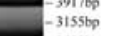 \\
\hline \multicolumn{2}{|l|}{ D-glucose } & +++ & +++ & - $1900 \mathrm{bp}$ & -389360 & $\begin{array}{l}-26636 s \\
-23756 p\end{array}$ \\
\hline \multicolumn{2}{|l|}{ D-fructose } & +++ & +++ & & $-26877 p_{p}$ & $-20936 p$ \\
\hline \multicolumn{2}{|l|}{ D-mannose } & +++ & +++ & $-1496 \mathrm{bp}$ & -235100 & $\begin{array}{l}-180550 \\
-165750\end{array}$ \\
\hline \multicolumn{2}{|c|}{ L-rhamnose } & +++ & - & & & $\begin{array}{ll}-1654400 \\
\end{array}$ \\
\hline \multicolumn{2}{|c|}{ Methyl- $\alpha$ D-mannopyranoside } & ++ & - & & $\begin{array}{l}-186606 \\
-1705500\end{array}$ & -137860 \\
\hline \multicolumn{2}{|c|}{$\mathrm{N}$-acetylglucosamine } & ++ & +++ & & 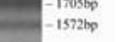 & \\
\hline \multicolumn{2}{|c|}{ Amigdalin } & ++ & +++ & $=-10000 \mathrm{p}$ & -138140 & 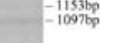 \\
\hline \multicolumn{2}{|l|}{ Arbutin } & ++ & +++ & - $=003 \mathrm{pp}$ & -128860 & -9 satpp \\
\hline \multicolumn{2}{|l|}{ Esculin } & +++ & +++ & $-800.006 \mathrm{pp}$ & -120060 & \\
\hline \multicolumn{2}{|l|}{ Salicin } & +++ & +++ & & & 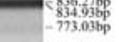 \\
\hline \multicolumn{2}{|l|}{ D-cellobiose } & +++ & +++ & -701.1960 & $\begin{array}{l}-101060 \\
100160\end{array}$ & \\
\hline \multicolumn{2}{|l|}{ D-maltose } & - & +++ & $-594.760 \mathrm{pp}$ & 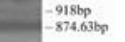 & \\
\hline \multicolumn{2}{|l|}{ D-melibiose } & - & +++ & & & \\
\hline \multicolumn{2}{|l|}{ D-saccharose } & - & +++ & $-501.826 \mathrm{bp}$ & -7332600 & $-548.28 \mathrm{bp}$ \\
\hline \multicolumn{2}{|l|}{ D-trehalose } & +++ & +++ & & -686.2600 & $-472.66 \mathrm{bp}$ \\
\hline \multicolumn{2}{|l|}{ D-raffinose } & - & +++ & & & \\
\hline \multicolumn{2}{|l|}{ Gentiobiose } & ++ & ++ & -39.3250 & & $-407.6 \mathrm{spp}$ \\
\hline \multicolumn{2}{|c|}{ D-tagatose } & +++ & +++ & & $-\$ 0.035 \%$ & \\
\hline \multicolumn{2}{|c|}{ Potassium gluconate } & + & - & -300.0060 & -501.0760 & \\
\hline \multicolumn{2}{|c|}{ Potassium 2-ketogluconate } & - & + & & & \\
\hline \multicolumn{2}{|c|}{ Gas production $(+/-)$} & - & - & & & \\
\hline \multirow{3}{*}{$\begin{array}{l}\text { Tolerance to } \\
\text { temperature }\end{array}$} & $30^{\circ} \mathrm{C}$ & + & + & 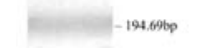 & & \\
\hline & $\begin{array}{l}37^{\circ} \mathrm{C} \\
15^{\circ} \mathrm{C}\end{array}$ & + & + & & 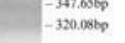 & \\
\hline & $\frac{45^{\circ} \mathrm{C}}{2 \text { ffter } 0 \text { h }}$ & $\frac{+}{0.500}$ & $\frac{-}{70}$ & $-145.786 p$ & & $-158.146 p$ \\
\hline $\begin{array}{l}\text { Acidified MRS } \\
\text { broth (pH 2.5) }\end{array}$ & 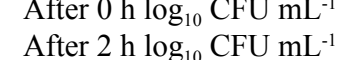 & $\begin{array}{l}8.5 \pm 0.2 \\
4.3 \pm 0.1\end{array}$ & $\begin{array}{l}7.9 \pm 0.2 \\
4.8 \pm 0.1\end{array}$ & -102.650 & & \\
\hline
\end{tabular}

$P a-P$. acidilactici, $P p-P$. pentosaceus; +++ - high growth (yellow), ++ - quite growth (green), + - little growth (dark green), -- not growth (blue)

P. acidilactici was found to be $4.3 \pm 0.1 \log _{10} \mathrm{CFU} \mathrm{mL}^{-1}$ and $P$. pentosaceus was $4.8 \pm 0.1 \log _{10} \mathrm{CFU} \mathrm{mL}^{-1}$ (Table 2). Gas production of tested strains was not observed.

$P$. acidilactici BaltBio01 and P. pentosaceus

BaltBio02 resistance to antibiotics. Modification of rumen fermentation by using feed additives, such as antibiotics, has proved to be a useful strategy to improve production efficiency in ruminants. However, the use of antibiotics has been increasing concern due to the potential appearance of residues in milk, meat and bacterial resistance. Furthermore, the use of antibiotics as a feed additive has been banned in the European Union (Russell, Houlihan, 2003). According to EFSA, as a basic requirement, the minimum inhibitory concentration of the antimicrobials should be determined for each of the following substances: GEN, KAN, STREP, TET, ERY, CLIN, CHL and AMP, also, resistance to AML and TM is very important (EFSA-FEEDAP, 2012). When a bacterial strain demonstrates higher resistance to a specific antimicrobial than the other strains of the same taxonomical unit, the presence of acquired resistance is indicated and additional information is needed on the genetic basis of the antimicrobial resistance. Any bacterial strain carrying an acquired resistance to antimicrobial that is shown to be due to the acquisition of genetic determinant presents the greatest potential for horizontal spread and should not be used as a feed additive. P. acidilactici BaltBio01 and P. pentosaceus BaltBio02 resistance to antibiotics is shown in Table 3.

The Pediococcus strains were considered non resistant to all EFSA recommended antibiotics, when the MIC $\left(\mathrm{mg} \mathrm{mL}^{-1}\right)$ values obtained were lower than the recommended breakpoint value, defined at species level by the FEEDAP (EFSA-FEEDAP, 2012). In the present study, $P$. acidilactici and $P$. pentosaceus were non resistant to GEN, KAN, STREP, TET, ERY, CLIN, CHL and AMP. Also, $P$. acidilactici and $P$. pentosaceus were non resistant to AML and TM, MIC values of $P$. acidilactici were 0.25 and $32 \mathrm{mg} \mathrm{mL}^{-1}$, and of $P$. pentosaceus -0.75 and $32 \mathrm{mg} \mathrm{mL}^{-1}$, respectively. Pediococcus strains used in the experiment showed to be non resistant to the tested antibiotics, and from this point of view these strains are safe for the use as starter cultures for fermented feed stock production.

Antibiotics are a major tool utilized by the health care industry to fight bacterial infections; however, bacteria are highly adaptable creatures and are capable of developing resistance to antibiotics. Consequently, decades of antibiotic use, or rather misuse, have resulted in bacterial resistance to many modern antibiotics. This antibiotic resistance can cause significant danger and suffering for many people and animals with common bacterial infections, those once easily treated with antibiotics. For several decades, studies on selection and dissemination of antibiotic resistance have focused mainly on clinically relevant species. However, recently many researchers have investigated commensal bacteria including LAB, which may act as reservoirs of antibiotic resistance genes similar to those found in human pathogens. The main threat associated with these bacteria is that they can transfer resistance genes to pathogenic bacteria.

Antimicrobial activities of $P$. acidilactici and P. pentosaceus and their mix. One of the most important modes of action of LAB is antimicrobial activity through inhibition of the pathogenic bacteria (Yang et al., 2015). Antimicrobial activities of $P$. acidilactici and 
Table 3. Inhibition of the growth of pathogenic bacteria by Pediococcus acidilactici, P. pentosaceus and mix of $P$. acidilactici with $P$. pentosaceus, and their resistance to antibiotics

\begin{tabular}{|c|c|c|c|c|c|c|c|}
\hline \multirow{5}{*}{ Microorganisms } & \multicolumn{3}{|c|}{ Zone of inhibition $\mathrm{mm}$} & \multirow{3}{*}{$\begin{array}{l}\text { Anti- } \\
\text { biotics }\end{array}$} & \multicolumn{3}{|c|}{ Resistance to antibiotics } \\
\hline & \multirow{4}{*}{$P a$} & \multirow{4}{*}{$P p$} & \multirow{4}{*}{$P a \times P p$} & & $P a$ & $P p$ & FEEDAP \\
\hline & & & & & \multicolumn{2}{|c|}{$\begin{array}{c}\mathrm{MIC} \\
\mathrm{mg} \mathrm{mL}^{-1}\end{array}$} & $\begin{array}{l}\text { breakpoint } \\
\mathrm{mg} \mathrm{mL}^{-1}\end{array}$ \\
\hline & & & & GEN & 12 & 14 & 16 \\
\hline & & & & TET & 2.5 & 2 & 8 \\
\hline Pseudomonas aeruginosa & $15.9 \pm 0.5$ & $17.3 \pm 0.6$ & $18.4 \pm 0.3$ & ERY & 0.19 & 0.25 & 1 \\
\hline Staphylococcus aureus & $16.3 \pm 0.6$ & $16.4 \pm 0.5$ & $17.2 \pm 0.5$ & AML & 0.25 & 0.75 & $\mathrm{nr}$ \\
\hline Escherichia coli & $15.8 \pm 0.3$ & $13.7 \pm 0.3$ & $16.1 \pm 0.4$ & $\mathrm{TM}$ & 32 & 32 & $\mathrm{nr}$ \\
\hline Salmonella enterica & $9.6 \pm 0.4$ & $11.3 \pm 0.3$ & $13.8 \pm 0.4$ & KAN & 32 & 24 & 64 \\
\hline Corynebacterium spp. & $11.4 \pm 0.3$ & $12.7 \pm 0.4$ & $13.9 \pm 0.3$ & STREP & 48 & 48 & 64 \\
\hline Klebsiella pneumoniae & $11.3 \pm 0.3$ & $11.6 \pm 0.6$ & $12.0 \pm 0.6$ & CLIN & 0.75 & 0.25 & 1 \\
\hline Enterococcus faecalis & $14.7 \pm 0.5$ & $13.3 \pm 0.3$ & $15.2 \pm 0.4$ & $\mathrm{CHL}$ & 3 & 2 & 4 \\
\hline Bacillus cereus & $11.4 \pm 0.3$ & $14.5 \pm 02$ & $15.4 \pm 0.5$ & AMP & 1.5 & 1 & 4 \\
\hline
\end{tabular}

Notes. Values are mean of three replicate analyses. $P a-P$. acidilactici, $P p-P$. pentosaceus; $P a \times P p-$ mix of $P$. acidilactici with $P$. pentosaceus; GEN - gentamicin, TET - tetracycline, ERY - erythromycin, AML - amoxicillin, TM - trimethoprim; KAN kanamycin, STREP - streptomycin, CLIN - clindamycin, CHL - chloramphenicol, AMP - ampicillin; MIC - minimum inhibitory concentration; FEEDAP - Panel on Additives and Products or Substances used in Animal Feed Breakpoint (EFSA-FEEDAP, 2012); $\mathrm{nr}$ - not required.

$P$. pentosaceus and their mix are presented in Table 3 . As could be seen from the results obtained, LAB supernatants inhibited the growth of all tested bacteria. The diameters of the inhibition zones of $P$. acidilactici toward pathogenic strains varied between $9.6 \pm 0.4$ and $16.3 \pm 0.6 \mathrm{~mm}$, of $P$. pentosaceus - between $11.3 \pm$ 0.3 and $17.3 \pm 0.6 \mathrm{~mm}$, and mix of $P$. acidilactici with P. pentosaceus - between $12.0 \pm 0.6$ and $18.4 \pm 0.3 \mathrm{~mm}$. In all the cases, higher antimicrobial activity demonstrated mix of $P$. acidilactici with $P$. pentosaceus, in compare with separate Pediococcus strains. The highest inhibition zones of $P$. acidilactici and $P$. pentosaceus mix were observed against Pseudomonas aeruginosa (inhibition zone diameter was $18.4 \pm 0.3 \mathrm{~mm}$ ); the lowest inhibition zones were observed against Klebsiella pneumoniae $(12.0 \pm 0.6 \mathrm{~mm})$.

Lactic acid bacteria (LAB) are characterised by many properties to control pathogens. These properties contain competence with pathogens in cell attachment, high adherence ability to intestinal epithelium, production of antibacterial substances such as organic acids, hydrogen peroxides, bacteriocins, etc. (Kermanshahi et al., 2015). Bacteriocins contribute to the biological control of pathogenic microorganisms. These metabolic compounds probably act synergistically (Choffnes et al., 2012). Bacteriocin production can be one of the most important factors for the successful establishment of probiotic bacteria (Asurmendi et al., 2015; Kermanshahi et al., 2015). Our previous studies showed, that Pediococcus strains, used in this experiment for dairy cattle feeding, produced bacteriocins ( $P$. acidilactici produced pediocin Ac05-7 and $P$. pentosaceus produced pediocin 05-8), and inhibited most of the food pathogenic bacteria (Cizeikiene et al., 2013). Also, data are published that the $P$. pentosaceus bacteriocin was active over a wide range of $\mathrm{pH}$ values and was stable to various heat treatments. This heat and $\mathrm{pH}$ stability may be useful if the bacteriocin is to be used as an antimicrobial agent in fermented or thermally processed substrates (Osmanagaoglu et al., 2011). This study showed that the higher antimicrobial activity could be achieved by using mix of selected Pediococcus strains, compared to separate strains usage.

Microbiological parameters and $\mathrm{pH}$ of fermented feed stock. The microbiological parameters and $\mathrm{pH}$ of the fermented feed stock are presented in Table 4. The count of LAB in the samples after $72 \mathrm{~h}$ of fermentation with $P$. acidilactici was $8.9 \pm 0.1 \log 10 \mathrm{CFU}$ $\mathrm{g}^{-1}$, and after $72 \mathrm{~h}$ of fermentation with $P$. pentosaceus was $9.6 \pm 0.4 \log 10 \mathrm{CFU} \mathrm{g^{-1 }}$. Fermentation inhibited growth of Enterobacteria and reduced the growth of total aerobic bacteria, yeast and mould in barley and wheat bran substrate. Reduction of mould growth in the fermented cereal bran samples was lower compared to yeast, but statistically significant $(p \leq 0.05)$.

The homo-fermentative LAB produce lactic acid as the major metabolic end product of carbohydrate fermentation, which leads to substrate $\mathrm{pH}$ reduction, and these changes have influence on growth inhibition of many microorganisms (Kermanshahi et al., 2015; Yang et al., 2015).

LAB are characterized by their tolerance to low $\mathrm{pH}$ and growth under this circumstance in which other bacteria are unable to grow, and thereby ensuring safety of fermented feed. Furthermore, penetration of lactic acid to the membranes leads to lowering the intracellular $\mathrm{pH}$ (Kermanshahi et al., 2015). The lowest $\mathrm{pH}$ was found after $72 \mathrm{~h}$ of fermentation. The results of the ANOVA test indicated that there was a significant effect of duration of fermentation on LAB count, total aerobic bacteria count, Enterobacteria count and yeast count $(p=0.0001)$ in barley and wheat substrate. However, significant influence of duration of fermentation on mould count was not found.

The hetero-fermentative LAB produces lactic acid and additional products such as acetic acid, ethanol and carbon dioxide. Ethanol is a part of intermediary products that are converted into produce $\mathrm{CO}_{2}$ and $\mathrm{H}_{2}$. Carbon dioxide interacts with cell membranes by reducing internal and external $\mathrm{pH}$ levels. Diacetyl is a product of citrate metabolism, and peroxide oxidizes membrane lipids and cell proteins (Choffnes et al., 2012; Kermanshahi et al., 2015). Also, bacteriocins produced by LAB affect membranes, DNA synthesis and protein synthesis. P. pentosaceus and P. acidilactici strains have capability to produce bacteriocins (Cizeikiene et al., 2013). Bacteriocins contribute to the biological control of pathogenic and spoilage microorganisms. The results of the ANOVA test indicated that there was a significant effect of the type of Pediococcus used for the cereal bran fermentation on substrate $\mathrm{pH}(p=0.0001)$, LAB count $(p=0.0001)$, total aerobic bacteria count $(p=0.0001)$, Enterobacteria count $(p=0.0001)$, yeast count $(p=0.0002)$ and mould count $(p=0.0004)$. The interaction between 
Table 4. Microbiological parameters of fermented feed stock

\begin{tabular}{|c|c|c|c|c|c|c|}
\hline \multirow{3}{*}{ Samples } & \multirow{3}{*}{$\begin{array}{c}\text { Fermentation } \\
\text { time } \\
\mathrm{h}\end{array}$} & \multirow{2}{*}{$\begin{array}{c}\text { Lactic acid } \\
\text { bacteria }\end{array}$} & \multirow{2}{*}{$\begin{array}{l}\text { Total aerobic } \\
\text { bacteria }\end{array}$} & \multirow{2}{*}{ Enterobacteria } & \multicolumn{2}{|c|}{ Fungi } \\
\hline & & & & & yeast & mould \\
\hline & & \multicolumn{5}{|c|}{$\log _{10} \mathrm{CFU} \mathrm{g}^{-1}$} \\
\hline Nonfer-mented & 0 & $4.6 \pm 0.1 \mathrm{a}$ & $5.4 \pm 0.1 \mathrm{c}$ & $5.9 \pm 0.2$ & $6.1 \pm 0.2 \mathrm{~d}$ & $4.6 \pm 0.1 \mathrm{~b}$ \\
\hline \multirow{3}{*}{$P a$} & 24 & $8.2 \pm 0.3 \mathrm{~d}$ & $4.3 \pm 0.2 b$ & - & $5.5 \pm 0.3 c$ & $4.2 \pm 0.4 \mathrm{a}$ \\
\hline & 48 & $9.4 \pm 0.1 \mathrm{~d}$ & $4.3 \pm 0.3 b$ & - & $5.3 \pm 0.1 \mathrm{c}$ & $4.0 \pm 0.2 \mathrm{a}$ \\
\hline & 72 & $8.9 \pm 0.1 \mathrm{~d}$ & $4.7 \pm 0.1 b$ & - & $5.1 \pm 0.3 \mathrm{a}$ & $4.0 \pm 0.1 \mathrm{a}$ \\
\hline \multirow{3}{*}{$P p$} & 24 & $8.4 \pm 0.3 b$ & $4.4 \pm 0.2 \mathrm{~b}$ & - & $5.7 \pm 0.3 c$ & $4.4 \pm 0.2 \mathrm{a}$ \\
\hline & 48 & $9.3 \pm 0.2 \mathrm{~d}$ & $4.6 \pm 0.4 b$ & - & $5.4 \pm 0.4 b$ & $4.3 \pm 0.3 \mathrm{a}$ \\
\hline & 72 & $9.6 \pm 0.4 \mathrm{~d}$ & $4.6 \pm 0.3 \mathrm{~b}$ & - & $5.2 \pm 0.2 \mathrm{a}$ & $4.3 \pm 0.2 \mathrm{a}$ \\
\hline \multirow{3}{*}{$P a \times P p$} & 24 & $7.7 \pm 0.2 b$ & $4.4 \pm 0.3 b$ & - & $5.8 \pm 0.2 \mathrm{c}$ & $4.0 \pm 0.3 \mathrm{a}$ \\
\hline & 48 & $8.6 \pm 0.2 \mathrm{~d}$ & $4.6 \pm 0.2 \mathrm{~b}$ & - & $5.2 \pm 0.1 \mathrm{~b}$ & $3.9 \pm 0.1 \mathrm{a}$ \\
\hline & 72 & $9.8 \pm 0.3 \mathrm{~d}$ & $4.4 \pm 0.1 \mathrm{~b}$ & - & $5.1 \pm 0.3 \mathrm{a}$ & $3.9 \pm 0.1 \mathrm{a}$ \\
\hline
\end{tabular}

Notes. $P a$ - fermented with $P$. acidilactici, $P p$ - fermented with $P$. pentosaceus, $P a \times P p-$ mix of $P$. acidilactici with pentosaceus; $\mathrm{CFU}$ - colony forming units. Values are mean of three replicate analyses. Different letters indicate significant differences between mean values of treatments $(p<0.05)$.

the analysed factors (duration of fermentation and type of Pediococcus used for cereal bran fermentation) was determined as statistically significant on the LAB count $(p<0.0019)$ and $\mathrm{pH}(p<0.0001)$ of cereal bran substrate.

The influence of $P$. acidilactici, $P$. pentosaceus and mix of $P$. acidilactici with $P$. pentosaceus fermented feed stock supplements on dairy cattle feed intake, milk production and milk composition. The influence of (with $P$. acidilactici, $P$. pentosaceus and mix of $P$. acidilactici with $P$. pentosaceus) fermented feed stock supplements on dairy cattle feed intake, milk production and milk composition is shown in Tables 5 and 6.

At the beginning of the experiment (feeding day 0) no significant differences in feed intake, milk production and milk composition between the different groups of dairy cattle were established. After 33 days of feeding with fermented feed stock supplements statistically significant milk yield increase in group D (compared with group A and group C) was established ( $p=0.008$ and $p=0.02$, respectively). After 66 days of feeding with fermented feed stock supplements similar trends were found, i.e. milk yield significantly $(p=0.001)$ increased in group D (compared to group A), and FCM significantly increased in groups $\mathrm{B}$ and $\mathrm{C}$, compared to control group (A) ( $p=0.02$ and $p=0.03$, respectively).
However, significantly higher FCM was established in group $\mathrm{D}$, compared to groups B and C ( $p=$ 0.05 and $p=0.03$, respectively). Dairy cattle production is generally expressed in terms of daily milk production, FCM or feed efficiency. The inclusion of microbial supplements in feed benefits the dairy cattle with already developed rumen by increasing palatability, stimulating cellulolytic bacteria and thus the rumen fermentation, improving nutrient digestibility in the rumen, preventing a decline in rumen $\mathrm{pH}$ by decreasing lactic acid production and/or increasing utilization of lactic acid by some bacteria and hence improve productivity (El-Din, Nour, 2015). Increased production of milk protein and fat might indicate that changes in rumen fermentation as a result of feeding with microorganisms enriched supplements increased the supply of glucogenic, aminogenic and lipogenic substrates (Erasmus et al., 2005). Explanation for increased synthesis of milk protein is a possible change in the profile of intestinally absorbed amino acids (Schwab et al., 1992). Our previous studies showed that by using $P$. acidilactici and $P$. pentosaceus strains it is possible to increase digestibility of soybean and to reduce activity of trypsin inhibitors (Bartkiene et al., 2015), therefore soybean meal was included in the diets of the investigated dairy cattle.

Table 5. Feed intake, milk production, and milk composition of dairy cattle fed with Pediococcus acidilactici, $P$. pentosaceus and mix of $P$. acidilactici with $P$. pentosaceus fermented feed stock supplements

\begin{tabular}{|c|c|c|c|c|}
\hline Groups & Group A & Group B & Group C & Group D \\
\hline \multicolumn{5}{|c|}{ Daily feed intake } \\
\hline Total kg DM & $20.01 \pm 0.72$ & $20.20 \pm 0.70$ & $20.14 \pm 0.71$ & $20.26 \pm 0.58$ \\
\hline \multicolumn{5}{|c|}{ Milk parameters } \\
\hline \multicolumn{5}{|c|}{ Feeding day 0} \\
\hline Yield kg d $^{-1}$ & $30.75 \pm 5.18$ & $29.50 \pm 3.31$ & $29.82 \pm 4.59$ & $30.03 \pm 5.36$ \\
\hline $4 \% \mathrm{FCM} \mathrm{kg} \mathrm{d}^{-1}$ & $30.87 \pm 4.16$ & $30.01 \pm 4.41$ & $30.03 \pm 4.28$ & $30.39 \pm 4.66$ \\
\hline Fat $\%$ & $4.08 \pm 0.48$ & $4.12 \pm 0.64$ & $4.08 \pm 0.56$ & $4.13 \pm 0.52$ \\
\hline Protein \% & $3.24 \pm 0.25$ & $3.22 \pm 0.38$ & $3.28 \pm 0.39$ & $3.27 \pm 0.24$ \\
\hline Lactose \% & $4.47 \pm 0.15$ & $4.48 \pm 0.17$ & $4.45 \pm 0.13$ & $4.53 \pm 0.12$ \\
\hline Urea mg dL $\mathrm{d}^{-1}$ & $15.20 \pm 2.20$ & $15.80 \pm 2.74$ & $15.50 \pm 2.12$ & $15.40 \pm 2.32$ \\
\hline \multicolumn{5}{|c|}{ Feeding day 33} \\
\hline Yield $\mathrm{kg} \mathrm{d}^{-1}$ & $29.93 \pm 3.55$ & $31.42 \pm 4.37$ & $30.24 \pm 3.99$ & $34.64 \pm 3.56$ \\
\hline $4 \% \mathrm{FCM} \mathrm{kg} \mathrm{d}^{-1}$ & $29.82 \pm 2.49$ & $32.03 \pm 3.26$ & $30.90 \pm 3.75$ & $35.38 \pm 2.31$ \\
\hline Fat $\%$ & $4.01 \pm 0.47$ & $4.17 \pm 0.47$ & $4.19 \pm 0.79$ & $4.18 \pm 0.50$ \\
\hline Protein \% & $3.27 \pm 0.16$ & $3.38 \pm 0.45$ & $3.29 \pm 0.57$ & $3.28 \pm 0.24$ \\
\hline Lactose \% & $4.51 \pm 0.13$ & $4.43 \pm 0.14$ & $4.54 \pm 0.12$ & $4.53 \pm 0.10$ \\
\hline Urea $\mathrm{mg} \mathrm{dL} \mathrm{dL}^{-1}$ & $17.10 \pm 2.92$ & $16.80 \pm 2.90$ & $16.40 \pm 1.84$ & $16.30 \pm 2.26$ \\
\hline \multicolumn{5}{|c|}{ Feeding day 66} \\
\hline Yield kg d $^{-1}$ & $29.04 \pm 3.88$ & $31.96 \pm 4.27$ & $31.74 \pm 4.37$ & $35.04 \pm 3.04$ \\
\hline $4 \% \mathrm{FCM} \mathrm{kg} \mathrm{d}^{-1}$ & $29.16 \pm 2.57$ & $32.72 \pm 3.70$ & $32.52 \pm 3.61$ & $35.99 \pm 3.14$ \\
\hline Fat $\%$ & $4.10 \pm 0.82$ & $4.20 \pm 0.51$ & $4.21 \pm 0.49$ & $4.21 \pm 0.62$ \\
\hline Protein \% & $3.40 \pm 0.31$ & $3.39 \pm 0.48$ & $3.35 \pm 0.41$ & $3.42 \pm 0.33$ \\
\hline Lactose \% & $4.55 \pm 0.13$ & $4.45 \pm 0.22$ & $4.48 \pm 0.13$ & $4.54 \pm 0.13$ \\
\hline Urea $\mathrm{mg} \mathrm{dL} \mathrm{dL}^{-1}$ & $16.70 \pm 2.36$ & $16.20 \pm 2.70$ & $15.70 \pm 2.11$ & $17.00 \pm 2.36$ \\
\hline
\end{tabular}

DM - dry matter, FCM - 4\% fat-corrected milk; group A - control (basal diet), group B - basal diet plus supplement with $P$. acidilactici, group C - basal diet plus supplement with P. pentosaceus, group D - basal diet plus supplement with P. acidilactici and P. pentosaceus mix 
Table 6. The influence of Pediococcus acidilactici, $P$. pentosaceus and mix of P. acidilactici with $P$. pentosaceus supplements on feed intake, milk production and milk composition of dairy cattle

\begin{tabular}{|c|c|c|c|c|c|c|c|c|c|}
\hline \multicolumn{10}{|c|}{$p$-value } \\
\hline $\begin{array}{c}\text { Differences } \\
\text { between groups }\end{array}$ & $\mathrm{A} v s \mathrm{~B}$ & $\mathrm{~A} v s \mathrm{C}$ & $\mathrm{A} v s \mathrm{D}$ & $\mathrm{B} v s \mathrm{C}$ & $\mathrm{B} v s \mathrm{D}$ & $\mathrm{C} v s \mathrm{D}$ & $\begin{array}{c}\mathrm{B} \mathrm{d} 0 v s \mathrm{~d} 33 / \\
\mathrm{B} \mathrm{d} 0 v s \mathrm{~d} 66\end{array}$ & $\begin{array}{c}\mathrm{C} d 0 \text { vs d33 / } \\
\mathrm{Cd} \text { d0 vs d66 }\end{array}$ & $\begin{array}{c}\mathrm{D} \mathrm{d} 0 \text { vs } \mathrm{d} 33 / \\
\mathrm{D} \mathrm{d} 0 \text { vs } \mathrm{d} 66\end{array}$ \\
\hline \multicolumn{10}{|c|}{ Daily feed intake } \\
\hline Total kg DM & 0.35 & 0.52 & 0.19 & 0.78 & 0.76 & 0.56 & - & - & - \\
\hline \multicolumn{10}{|c|}{ Milk parameters } \\
\hline \multicolumn{10}{|c|}{ Feeding day 0} \\
\hline Yield kg d $\mathrm{k}^{-1}$ & 0.53 & 0.68 & 0.77 & 0.86 & 0.79 & 0.93 & - & - & - \\
\hline $4 \% \mathrm{FCM} \mathrm{kg} \mathrm{d}^{-1}$ & 0.66 & 0.66 & 0.81 & 0.99 & 0.86 & 0.86 & - & - & - \\
\hline Fat $\%$ & 0.88 & 0.99 & 0.84 & 0.90 & 0.97 & 0.86 & - & - & - \\
\hline Protein \% & 0.90 & 0.76 & 0.79 & 0.72 & 0.74 & 0.92 & - & - & - \\
\hline Lactose $\%$ & 0.87 & 0.71 & 0.32 & 0.61 & 0.46 & 0.15 & - & - & - \\
\hline Urea $\mathrm{mg} \mathrm{dL}^{-1}$ & 0.60 & 0.76 & 0.85 & 0.79 & 0.73 & 0.92 & - & - & - \\
\hline \multicolumn{10}{|c|}{ Feeding day 33} \\
\hline Yield kg d ${ }^{-1}$ & 0.41 & 0.86 & 0.008 & 0.54 & 0.09 & 0.02 & 0.28 & 0.83 & 0.04 \\
\hline $4 \% \mathrm{FCM} \mathrm{kg} \mathrm{d}^{-1}$ & 0.11 & 0.46 & 0.001 & 0.48 & 0.02 & 0.005 & 0.26 & 0.63 & 0.007 \\
\hline Fat $\%$ & 0.45 & 0.54 & 0.45 & 0.55 & 0.98 & 0.96 & 0.83 & 0.72 & 0.83 \\
\hline Protein $\%$ & 0.48 & 0.92 & 0.92 & 0.71 & 0.55 & 0.96 & 0.39 & 0.96 & 0.88 \\
\hline Lactose $\%$ & 0.20 & 0.65 & 0.74 & 0.10 & 0.10 & 0.87 & 0.46 & 0.14 & 0.91 \\
\hline Urea mg dL $\mathrm{dL}^{-1}$ & 0.82 & 0.53 & 0.50 & 0.72 & 0.67 & 0.91 & 0.44 & 0.32 & 0.39 \\
\hline \multicolumn{10}{|c|}{ Feeding day 66} \\
\hline Yield kg d ${ }^{-1}$ & 0.13 & 0.16 & 0.001 & 0.91 & 0.08 & 0.07 & 0.17 & 0.35 & 0.02 \\
\hline $4 \% \mathrm{FCM} \mathrm{kg} \mathrm{d}^{-1}$ & 0.02 & 0.03 & 0.001 & 0.90 & 0.05 & 0.03 & 0.15 & 0.18 & 0.006 \\
\hline Fat $\%$ & 0.76 & 0.73 & 0.75 & 0.96 & 0.97 & 1.00 & 0.77 & 0.61 & 0.77 \\
\hline Protein \% & 0.94 & 0.74 & 0.88 & 0.84 & 0.85 & 0.66 & 0.38 & 0.70 & 0.23 \\
\hline Lactose $\%$ & 0.24 & 0.21 & 0.79 & 0.76 & 0.31 & 0.31 & 0.75 & 0.59 & 0.93 \\
\hline Urea mg dL ${ }^{-1}$ & 0.66 & 0.33 & 0.78 & 0.65 & 0.49 & 0.21 & 0.75 & 0.84 & 0.14 \\
\hline
\end{tabular}

$\mathrm{DM}$ - dry matter, FCM - 4\% fat-corrected milk; group A - control (basal diet), group B - basal diet plus supplement with $P$. acidilactici, group $\mathrm{C}$ - basal diet plus supplement with $P$. pentosaceus, group D - basal diet plus supplement with $P$. acidilactici and P. pentosaceus mix; $p$-value contrast: $\mathrm{A} v s \mathrm{~B}=$ group A $v s$ group $\mathrm{B}, \mathrm{A} v s \mathrm{C}=$ group $\mathrm{A}$ vs group $\mathrm{C}, \mathrm{A} v s \mathrm{D}=$ group $\mathrm{A} v s$ group $\mathrm{D}, \mathrm{B} v s \mathrm{C}=$ group B $v s$ group C, B $v s \mathrm{D}-$ group B $v s$ group $\mathrm{D}, \mathrm{C} v s \mathrm{D}-$ group $\mathrm{C} v s$ group $\mathrm{D} ; \mathrm{B} \mathrm{d} 0 v s \mathrm{~d} 33 / \mathrm{B} \mathrm{d} 0 v s \mathrm{~d} 66-\mathrm{day} 0 v s$ day 33 and day $0 v s$ day 66 in group $\mathrm{B} ; \mathrm{C} \mathrm{d} 0 v s \mathrm{~d} 33 / \mathrm{C} 0$ d $v s \mathrm{~d} 66$ - day $0 v s$ day 33 and day 0 vs day 66 in group $\mathrm{C} ; \mathrm{D} \mathrm{d} 0 v s \mathrm{~d} 33 /$ $\mathrm{D} \mathrm{d} 0 v s \mathrm{~d} 66$ - day $0 v s$ day 33 and day $0 v s$ day 66 in group D

\section{Conclusions}

1. The isolated Pediococcus acidilactici BaltBio01 and $P$. pentosaceus BaltBio02 strains demonstrated versatile carbohydrate metabolism, grown at $30^{\circ} \mathrm{C}$ and $37^{\circ} \mathrm{C}$, and acidic tolerance, also showed to be non resistant to the tested antibiotics and have antimicrobial activity against undesirable microorganisms.

2. Mixture of barley and wheat bran is a suitable substrate to produce safer (reduced Enterobacteria, total aerobic bacteria, yeast and mould count) feed with high content of Pediococcus.

3. Significantly higher milk yield (after 33 days) could be obtained by using Pediococcus mix (P. acidilactici BaltBio01 $\times$ P. pentosaceus BaltBio02) cultivated in cereal by-products for dairy cattle feeding.

Received 23092016

Accepted 09122016

\section{References}

Allen H. K., Levine U. Y., Looft T., Bandrick M., CaseyT.A. 2013. Treatment, promotion, commotion: antibiotic alternatives in food-producing animals. Trends in Microbiologv, 21 (3): 114 119 https://doi.org/10.1016/j.tim.2012.11.001

Asurmendi P., Garcia M. J., Pascual L., Barberis L. 2015. Biocontrol of Listeria monocytogenes by lactic acid bacteria isolated from brewer's grains used as feedstuff in Argentina. Journal of Stored Products Research, 61: 27-31 https://doi.org/10.1016/j.jspr.2015.02.001

Balcazar J. L., de Blas I., Ruiz-Zarzuela I., Cunningham D., Vendrell D., Muzquiz J. L. 2006. The role of probiotics in aquaculture. Veterinary Microbiologv. 114 (3): 173-186 https://doi.org/10.1016/j.vetmic.2006.01.009

Bartkiene E., Krungleviciute V., Juodeikiene G., Vidmantiene D., Maknickiene Z. 2015. Solid state fermentation with lactic acid bacteria to improve the nutritional quality of lupin and soya bean. Journal of the Science of Food and Agriculture, 95 (6): 1336-1342 https://doi.org/10.1002/jsfa.6827

Chaucheyras-Durand F., Durand H. 2010. Probiotics in animal nutrition and health. Beneficial Microbes, 1: 3-9 https://doi.org/10.3920/BM2008.1002
Choffnes E. R., Relman D. A., Olsen L., Hutton R., Mack A. 2012. Improving food safety through a one health approach: workshop summary. USA, $418 \mathrm{p}$.

Cizeikiene D., Juodeikiene G., Paskevicius A., Bartkiene E. 2013. Antimicrobial activity of lactic acid bacteria against pathogenic and spoilage microorganism isolated from food and their control in wheat hread. Fond Control, 31 (2): 539-545 https://doi.org/10.1016/j.foodcont.2012.12.004

Coda R., Katina K., Rizzello C. G. 2015. Bran bioprocessing for enhanced functional properties. Current Opinion in Inurnal of Fond Science 1. 50-55 https://doi.org/10.1016/j.cofs.2014.11.007

Connor P. M. U., Koss K. P., Hill C., Cotter P. D. 2015. Antimicrobial antagonists against food pathogens: a bacteriocin perspective. Food Microbiology, 2: 51-57

Di Cello F., Bevivino A., Chiarini L., Fani R., Paffetti D. Tabacchioni S., Dalmastri C. 1997. Biodiversity of a Burkholderia cepacia population isolated from the maize rhizosphere at different plant growth stages. Applied and Environmental Microbiology, 63 (11): 4485-4493

Dimitonova P. S., Bakalov-Vladimirov B., AleksandrovaGeorgieva R. N., Trifonova D. S. 2008. Phenotypic and molecular identification of lactobacilli isolated from vaginal secretions. Journal of Microbiology, 41 (6): 469-477

EFSA. 2011. Maintenance of the list of QPS biological agents intentionally added to food and feed (2011 update). The EFSA Journal, 9 (12): 1-82

EFSA-FEEDAP. 2012. Guidance on the assessment of bacterial susceptibility to antimicrobials of human and veterinary imnortance. FFSA Iournal, 10 (6): 2740-2749 https://doi.org/10.2903/j.efsa.2012.2740

El-Din A. N. M., Nour M. I. L. K. 2015. Production and some blood metabolite responses to yeast supplementation in early lactating Holstein dairy cows. Egyptian Journal of Animal Production, 52 (1): 11-17

Erasmus L. J., Robinson P. H., Ahmadib A., Hinders R., Garrett J. E. 2005. Influence of prepartum and postpartum supplementation of a yeast culture and monensin, or both, on ruminal fermentation and performance of multiparous dairy cows Animal Feed Science and Technolnofl 17): 219-239 https://doi.org/10.1016/j.anifeedsci.2005.03.004

FAO/WHO. 2006. Probiotics in food. Health and nutritional properties and guidelines for evaluation. FAO Food Nutrition Paper, 85: 1-50 
Kermanshahi K. R., Hojati V., Shiravi A. 2015. Zinc oxide nanoparticles absorption rate in the heart tissue of female mice. Journal of Chemical Health Risks, 5 (3): 193-198

Kiss H., Kögler B., Petricevic L., Sauerzapf I., Klayraung S., Domig K. J., Viernstein, H., Kneifel W. 2007. Vaginal Lactobacillus microbiota of healthy women in the late first trimester of pregnancy. International Journal of Obstetrics and Gynaecology, 114 (11): 1402-1407 https://doi.org/10.1111/j.1471-0528.2007.01412.x

Lee J., Yun H. S., Cho K. W., Uh S., Kim S. H., Chun T. 2011. Evaluation of probiotic characteristics of newly isolated Lactobacillus spp.: immune modulation and longevity. International Journal of Food Microbiology, 148 (2): 80 86 https://doi.org/10.1016/j.ijfoodmicro.2011.05.003

Mora D., Fortina M. G., Parini C., Manachini P. L. 1997. Identification of Pediococcus acidilactici and Pediococcus pentosaceus based on 16S rRNA and ldhD gene-targeted multiplex PCR analysis. FEMS Microbiology Letter, 151 (2): 231-236 https://doi.org/10.1111/j.1574-6968.1997.tb12575.x

Muñoz-Atienza E., Gómez-Sala B., Araújo C., Campanero C., Campo del R., Hernández P. E., Herranz C., Cintas L. M. 2013. Antimicrobial activity, antibiotic susceptibility and virulence factors of Lactic Acid Bacteria of aquatic origin intended for use as probiotics in aquaculture. BMC Microbiology, 13: 15 https://doi.org/10.1186/1471-2180-13-15

Osmanagaoglu O., Kiran F., Nes I. F. 2011. A probiotic bacterium, Pediococcus pentosaceus OZF, isolated from human breast milk produces pediocin $\mathrm{AcH} / \mathrm{P}$ A-1. African Journal of Biotechnology, 10 (11): 2070-2079

Pfannebecker J., Fröhlich J. 2008. Use of a species-specific multiplex PCR for the identification of pediococci. International Journal of Food Microbiology, 10 (2): 288296 https://doi.org/10.1016/j.ijfoodmicro.2008.08.019

Redondo L.M., Chacana P.A., DominguezJ.E., Miyakawa M. E. F. 2014. Perspectives in the use of tannins as alternative to antimicrobial growth promoter factors in poultry. Frontiers in Microbiologv, 5: 118

https://doi.org/10.3389/fmicb.2014.00118

Russell J. B., Houlihan A. J. 2003. Ionophore resistance of ruminal bacteria and its potential impact on human health. FEMS Microbiology Reviews, 27 (1): 65-74 https://doi.org/10.1016/S0168-6445(03)00019-6

Salvedia C. B., Supangco E. P., Vega R. S. A., Elegado F. B., Rayos A. A. 2015. Effect of probiotic feeding on milk yield and components of crossbred dairy goats. Philippine Journal of Veterinary and Animal Sciences, 41 (1): 21-30

Schwab C. G., Bozak C. K., Whitehouse N. L., Mesbah M. M. A. 1992. Amino acid limitation and flow to the duodenum at four stages of lactation. I. Sequence of lysine and methionine limitation. Journal of Dairy Sciences, 75 (12): 3486-3502 https://doi.org/10.3168/jds.S0022-0302(92)78125-9

Shreedhar J. N., Patıl M., Gulbarga K. V. K., Kumar P. 2016. Effect of probiotics supplementation on milk yield and its composition in lactating Holstein Fresien and Deoni cross bred cows. Inurnal of Medical and Binengineering, 5 (1): 19-23 https://doi.org/10.12720/jomb.5.1.19-23

Valstybès žinios, 2012-11-10, Nr. 130-6595 https://e-seimas. lrs.lt/portal/legalAct/lt/TAD/TAIS.437081 (in Lithuanian)

Versalovic J., Schneider M., De Bruijn F., Lupski J. R. 1994. Genome fingerprinting of bacteria using repetitive sequence-based polymerase chain reaction. Methods in Molecular and Cellular Biology, 5: 25-40

Vibhute V. M., Shelke R. R., Chavan S. D., Nage S. P. 2011. Effect of probiotics supplementation on the performance of lactating crossbred cows. Veterinary World 4 (12): 557-561 https://doi.org/10.5455/vetworld.2011.557-561

Yang F., Hou C., Zeng X., Qiao S. 2015. The use of lactic acid bacteria as a probiotic in swine diets. Pathogens, 4 (1): 34-45 https://doi.org/10.3390/pathogens4010034

Yirga J. 2015. 'The use of probiotics in animal nutrition. Journal of Prohintics and Health. 3:132

https://doi.org/10.4172/2329-8901.1000132

ISSN 1392-3196 / e-ISSN 2335-8947

Zemdirbyste-Agriculture, vol. 104, No. 1 (2017), p. 63-70

DOI $10.13080 /$ z-a.2017.104.009

\section{Pediokokų kamienų panaudojimas grūdụ sẻlenų fermentacijai ir įtaka pieninių galvijụ primilžiui}

V. Krunglevičiūtè, R. Želvyte, I. Monkevičienė, J. Kantautaite, R. Stankevičius, M. Ružauskas, E. Bartkienè

Lietuvos sveikatos mokslų universitetas

\section{Santrauka}

Iš savaiminiu būdu fermentuotų rugiu išskirtos Pediococcus acidilactici BaltBio01 ir Pediococcus pentosaceus BaltBio02 padermės buvo panaudotos miežinių ir kvietinių sėlenų (santykiu 90:10 \%) fermentacijai. Pagaminta fermentuota pašarų žaliava, turinti didelị kiekį gyvybingų pediokokų, panaudota pieniniams galvijams (Lietuvos juodmargėms) šerti, ir ịvertinta fermentuotos pašarų žaliavos ịtaka pieninių galvijų primilžiui bei pieno suděčiai. Pediokokai P. acidilactici BaltBio01 ir P. pentosaceus BaltBio02 fermentavo daugelị tirtu angliavandenių, gerai augo 30 ir $37^{\circ} \mathrm{C}$ temperatūroje ir pasižymèjo atsparumu rūgštinei terpei. Išskirti pediokokai nebuvo atsparūs antibiotikams ir pasižymėjo antimikrobinèmis savybėmis. Grūdų gamybos šalutinių produktų (miežinių ir kvietinių sėlenų) biokonversija, taikant fermentaciją išskirtais mikroorganizmais, igalina pagaminti saugesnę (su mažesniu Enterobacteria, aerobinių bakterijų, mielių ir pelėsių kiekiu) fermentuotą pašarų žaliavą, turinčią didelị kieki gyvybingų pediokoku. Eksperimento pradžioje esminių skirtumų tarp pašaro suvartojimo, primilžio ir pieno sudèties nebuvo nustatyta. Eksperimento metu kontrolinès (A grupès) ir bandomujų grupių racionas buvo vienodas, tačiau bandomosios grupès 66 dienas papildomai gavo po $200 \mathrm{~g}$ gyvuliui fermentuotos pašaru žaliavos, kurioje buvo $9,6 \log _{10} \mathrm{KSV} \mathrm{g}^{-1}$ pediokokų (B grupès gyvuliai gavo po $200 \mathrm{~g}$ fermentuotos $P$. acidilactici pašarų žaliavos pieniniam galvijui/dieną, $\mathrm{C}$ grupe gavo po $200 \mathrm{~g} P$. pentosaceus fermentuotos pašaru žaliavos pieniniam galvijui/ dieną, o D grupė gavo po $200 \mathrm{~g} P$. acidilactici ir $P$. pentosaceus fermentuotos pašarų žaliavos pieniniam galvijui/ dieną). Po 33 dienų šèrimo nustatytas reikšmingas D grupès pieninių galvijų primilžio padidèjimas $(34,64 \pm 3,56$ $\left.\mathrm{kg} \mathrm{d}^{-1}\right)$, lyginant su A $\left(29,93 \pm 3,55 \mathrm{~kg} \mathrm{~d}^{-1}\right)$ ir $\mathrm{C}\left(30,24 \pm 3,99 \mathrm{~kg} \mathrm{~d}^{-1}\right)$ grupių pieninių galvijų primilžiu. Po 66 dienų šerimo nustatytos panašios tendencijos, t. y. reikšmingai $(p=0.001)$ didesnis primilžis buvo $\mathrm{D}$ grupés pieninių galvijų (35,04 $\left.\pm 3,04 \mathrm{~kg} \mathrm{~d}^{-1}\right)$, lyginant su A grupès pieninių galvijų primilžiu $\left(29,04 \pm 3,88 \mathrm{~kg} \mathrm{~d}^{-1}\right)$.

Apibendrinant galima teigti, kad miežinès ir kvietinès sèlenos gali būti naudojamos $P$. acidilactici BaltBio01 ir P. pentosaceus BaltBio02 padermėms gausinti, o didelị kiekị pediokokų turinti fermentuota pašarų žaliava gali būti rekomenduojama siekiant padidinti pieninių galvijų primilžị.

Reikšminiai žodžiai: fermentuota pašarų žaliava, miežinès ir kvietinès sėlenos, pediokokai, pienas, pieniniai galvijai. 